De grutter DOI: $10.1515 /$ plass-2015-0021

Valiollah Rameeh

Agronomic and Horticulture Crops Research Department, Mazandaran Agricultural and Natural Resources Research and Education Center, AREEO, Sari, Iran, e-mail: vrameeh@gmail.com

\title{
COMBINING ABILITY OF PHENOLOGICAL TRAITS AND SEED YIELD IN SPRING RAPESEED GENOTYPES
}

\begin{abstract}
Six parents and their $15 \mathrm{~F}_{2}$ diallel progenies, totally 21 genotypes, were evaluated for genetic parameters of quantitative characteristics. The traits of interest were growing degree days (GDDs) from sowing to the flowering (DDF), to end of flowering (DDE), flowering period (DFP), to maturity (DDM) and seed yield (SY). Significant mean squares of general combining ability (GCA) was exhibited for DDF, DDE, DFP, DDM and seed yield indicating significant differences of GCA effects of parents for these traits. Significant mean squares of specific combining ability (SCA) for all the traits exhibited the importance of non additive genetic effects for the traits. Significant ratio of MS(GCA)/MS(SCA) and high narrow sense heritability estimates for DDF, DDE, DDM indicating the prime importance of additive genetic effects for controlling these traits. DFP was also less heritable than the other phonological traits, so the efficiency of selection for this trait will be low. All of the combinations with significant negative SCA effects for DDM had at least one parent with significant negative GCA effect for this trait. PF7045/91 with significant positive GCA effect of SY, was best combiner for improving SY. Significant positive correlation between DDM and each of two traits including DDF and DDE, indicating these traits can be used as indirect selection criteria for improving DDM.
\end{abstract}

Key words: additive, diallel, GCA, narrow-sense heritability, rapeseed.

\section{INTRODUCTION}

Flowering is the most critical stage influencing the yield of oilseed rape. The unset of flower initiation can have strong influence on flower, pod and seed number

Communicated by Grzegorz Żurek 
(Diepenbrock, 2000; Downey and Rimer, 1993; Faraj, et. al., 2008). Habekotte (1997) used a sensitivity analysis within a crop growth model to study options for increasing seed yield in winter oilseed rape. The most promising crop type for high seed yield combined late maturity with early flowering (Downey and Rimer, 1993). Genetic information of rapeseed flowering and maturity could aid orienting breeding strategies for short- or long-growing seasons. Diallel crosses scheme is a useful mating design (Gardner and Eberhart, 1966) that has been widely used to obtain information on the general (GCA) and the specific combining ability (SCA) of parental lines and their hybrid crosses in different crops (Xiang and $\mathrm{Li}, 2001$ ). Information on GCA and SCA is very important in conducting a successful breeding program to achieve sufficient heterosis (Malik et al., 2004). Advanced in the phenological traits, yield components and seed yield of brassica requires certain information regarding the nature of combining ability of parents available for use in the hybridization program (Ali et al., 1995 ). In addition, information about the nature of gene action involved in expression of quantitative and qualitative traits of economic importance is also required to develop desirable lines. Studies on combining ability have been done earlier (Kumar et al., 2011; Nasimi et al., 2006; Singh et al., 2010). Various studies on spring cultivars of oilseed rape have shown the important role of GCA and SCA effects for days to flowering and also it be a highly heritable character determined by genes that exhibit some degree of dominance (Teklwold .and Becker, 2005; Hung, et al., 2010; Zhang and Zhu, 2006). Likewise, studies with winter cultivars of this species (Amiri-Oghana et al., 2009; Sabaghnia, et al., 2010) showed both additive and dominance gene effects to have a significant role in the inheritance of flowering time. Significant negative GCA and SCA effects were reported for days to flowering (Teklwold and Becker, 2005).

Most of the studies showed significant GCA and SCA effects for yield and its component characters indicating that both additive and nonadditive gene action were important in the inheritance of these traits (Azizinia, 2012; Sabaghnia, et al., 2010). Earlier breeders concluded in their research that with the changes in environment gene effects for different traits contributing to yield or yield itself changes in rapeseed $(B$. napus L.), therefore for different environment one has to suggest different selection criteria for the improvement in the yield. For those traits that are controlled by additive gene action, simple selection in early segregating generation is suggested, whereas for those traits controlled by non-additive gene action selection in later segregating generation would be more effective (Cheema and Sadaqat, 2004).

Scanning literatures have showed that a better understanding of the underlying genetic control of agronomically important traits in spring rapeseed are useful in breeding for early maturity and seed yield. The objectives of this study were to identify general and specific combining abilities and narrow-sense heritability for growing degree day (GDD) of phonological traits and seed yield 
in adapted rapeseed cultivars and also detecting the best general and specific combiners among different cultivars.

\section{MATERIALS AND METHODS}

Six spring cultivars of rapeseed (B. napus L.) which were selected based on their different agronomic characters were crossed in half diallel crosses during 2004-05. In order to produce $\mathrm{F} 2$ progenies, fifteen $\mathrm{F} 1$ populations from a $6 \times 6$ half diallel cross were selfed by light transparent white mesh cloth at Biekola Agriculture Research Station, located in Neka, Iran $\left(13^{\circ}, 53^{\prime} \mathrm{E}\right.$ longitude and $43^{\circ} 36^{\prime} \mathrm{N}$ latitude, 15 $\mathrm{m}$ above sea level) during winter 2005-06. F2 progenies along with 6 parents including RGS003, Option500, RW008911, RAS3/99, 19H and PF7045/91 were grown in a randomized complete block design with four replications during 2006-07. The plots related to each experiment were consisted of four rows $5 \mathrm{~m}$ long and $40 \mathrm{~cm}$ apart. The distance between plants on each row was 5 $\mathrm{cm}$ resulting in approximately 400 plants per plot, which were sufficient for F2 genetic analysis in each experiment. The soil was classified as a deep loam soil (Typic Xerofluents, USDA classification) contained an average of $280 \mathrm{~g}$ clay $\times \mathrm{kg}^{-1}, 560 \mathrm{~g}$ silt $\times \mathrm{kg}^{-1}, 160 \mathrm{~g}$ sand $\times \mathrm{kg}^{-1}$, and $22.4 \mathrm{~g}$ organic matter $\times \mathrm{kg}^{-1}$ with a $\mathrm{pH}$ of 7.3. Fertilizers were applied at the rates of 100 : 50: $90 \mathrm{~kg} \times \mathrm{ha}^{-1}$ of $\mathrm{N}: \mathrm{P}: \mathrm{K}$, respectively. All the plant protection measures were adopted to make the crop free from insects. Grain yield (adjusted to $\mathrm{kg} / \mathrm{ha}$ ) was recorded based on three middle rows of each plot.

Growing degree days (GDD) were computed for all flowering accessions by using the formula:

$$
G D D=\frac{(\operatorname{Min} T+\operatorname{Max} T)}{2}-\text { Base } T
$$

where $\operatorname{Min} T$ is the lowest temperature of the day and $\operatorname{Max} T$ is the highest temperature of the day; Temperature thresholds for Min T and Max $T$ were set to $0^{\circ} \mathrm{C}$ and $30^{\circ} \mathrm{C}$, respectively. Base $T$ is the temperature below which no development occurs and was set to $0^{\circ} \mathrm{C}$, based on recent research which indicated that it was more accurate for B. napus plant development than is the typical base temperature of $5^{\circ} \mathrm{C}$ (Thomas, 2003). The growing degree days (GDDs) were calculated for number of days from sowing to the flowering (DDF), to end of flowering (DDE) and maturity (DDM). The GDDs for flowering period (DFP) was also calculated for the difference between days to flowering and days to end of flowering. Seed yield (adjusted to $\mathrm{kg} \times \mathrm{ha}^{-1}$ ) was recorded based on two middle rows of each plot.

Analysis of variance for the crosses was based on Griffing's method 2, model 1 for fixed genotypes and the linear model(Griffings, 1956). Each effect was tested using its interaction with the block as error term. A $t$-test was used to test 
whether the GCA and SCA effects were different from 0 (Kearsey and Pooni, 1996; Zhang and Kang, 1997).

\section{RESULTS AND DISCUSSION}

\section{Diallel analysis of variance}

Significant mean squares of genotypes for growing degree days (GDDs) of number of days from sowing to the flowering (DDF), to end of flowering (DDE), for flowering period (DFP) and maturity (DDM) and seed yield (SY) indicating the existence of genetic variability among crosses and their parents for the traits (Table 1). Significant mean squares of general combining ability (GCA) was detected for DDF, DDE, DFP, DDM and seed yield indicated the significant differences of GCA effects of parents for these traits. Significant mean squares of specific combining ability (SCA) for all the traits exhibited significant differences of SCA effects of crosses for the traits. Significant ratio of MS(GCA)/MS(SCA) and high narrow sense heritability estimates for DDF, DDE, DDM indicating the prime importance role of additive genetic effects for these traits. Similarly, various studies on spring (Hung, et al., 2010, Rameeh 2011) and winter (Amiri-Oghana and et al., 2009; Sabaghnia, et al., 2010) cultivars of oilseed rape have shown the important role of additive genetic effects for phenological traits.

Table 1

Analysis of variance for growth degree day of phonological traits and seed yield based on Griffing's method two with mixed-B model

\begin{tabular}{|c|c|c|c|c|c|c|}
\hline \multirow{2}{*}{ S.O.V. } & \multirow{2}{*}{ DF } & \multicolumn{5}{|c|}{ M.S. } \\
\hline & & DDF & DDE & DFP & DDM & SY \\
\hline Replication & 3 & $645.38^{*}$ & $3729.11 * *$ & $5986.96^{* *}$ & $2835.84 * *$ & 276606.58 \\
\hline Cross & 20 & $2427.10 * *$ & $2147.52 * *$ & $1250.95 * *$ & $13490.96^{* *}$ & $456133.05^{* *}$ \\
\hline GCA & 5 & $8282.15^{* *}$ & $6733.52 * *$ & $2116.00 * *$ & $34638.11 * *$ & $493071.66^{*}$ \\
\hline SCA & 15 & $475.41 *$ & $618.86^{* *}$ & $962.60 * *$ & $6441.91 * *$ & $443820.18^{* *}$ \\
\hline Error & 60 & 224.85 & 197.14 & 370.36 & 733.01 & 146217.31 \\
\hline \multicolumn{2}{|c|}{ MS(GCA)/MS(SCA) } & $17.4^{* *}$ & $10.9^{* *}$ & 2.2 & $5.4 * *$ & 1.11 \\
\hline \multicolumn{2}{|c|}{ Degree of dominance } & 0.49 & 0.71 & 1.64 & 1.16 & 3.02 \\
\hline \multicolumn{2}{|c|}{ Narrow-sense heritability } & 0.90 & 0.89 & 0.54 & 0.92 & 0.15 \\
\hline
\end{tabular}

*, ** Significant at $\mathrm{p}=0.05$ and 0.01 , respectively; DDF: growing degree days (GDDs) to the flowering; DDE: GDDs to end of flowering; DFP: GDDs for flowering period; DDM: GDDs to maturity; SY: Seed yield 
General combining ability (GCA) and per se performance of parents

Table 2

The means of growth degree day (GDD) of phonological traits and seed yield six parents of B.napus

\begin{tabular}{lrrrrr}
\hline \multicolumn{1}{c}{ Parents } & $\mathrm{DDF}\left({ }^{\circ} \mathrm{C}\right)$ & \multicolumn{1}{c}{$\mathrm{DDE}\left({ }^{\circ} \mathrm{C}\right)$} & $\mathrm{DFP}\left({ }^{\circ} \mathrm{C}\right)$ & $\mathrm{DDM}\left({ }^{\circ} \mathrm{C}\right)$ & $\mathrm{SY}\left(\mathrm{kg} \times \mathrm{ha}^{-1}\right)$ \\
\hline 1-RAS3/99 & 861.05 & 1086.25 & 225.20 & 1569.76 & 2635.52 \\
2-RW008911 & 888.90 & 1129.33 & 240.43 & 1563.81 & 2505.83 \\
3-19H & 868.65 & 1140.40 & 271.75 & 1594.31 & 2447.92 \\
4-RGS 003 & 796.73 & 1094.75 & 298.03 & 1484.55 & 2971.84 \\
5-Option 500 & 873.13 & 1116.95 & 243.83 & 1537.30 & 2218.58 \\
6-PF7045/91 & 902.95 & 1155.70 & 252.75 & 1641.30 & 3131.92 \\
LSD $(\alpha=0.01)$ & 28.20 & 26.41 & 36.20 & 50.92 & 719.2 \\
\hline
\end{tabular}

DDF: growing degree days (GDDs) to the flowering; DDE: GDDs to end of flowering; DFP: GDDs for flowering period; DDM: GDDs to maturity; SY: Seed yield

Mean values of parents for DDF varied from $796.73^{\circ} \mathrm{C}$ to $902.95^{\circ} \mathrm{C}$ in RGS003 and PF7045/91, respectively (Table 2). Due to significant positive correlation between DDF and DDM,(Table 3), selection of low mean values of DDF make selection of low mean values of DDM, therefore low mean values of DDF and also its negative GCA effects will be preferable. Significant negative GCA effect of DDF for RGS003, for this line indicating additive genetic effects had decreasing effects for this trait (Table 4). In earlier studies (Hung, et al., 2010; Sabaghnia, et al., 2010; Rameeh 2011) were reported significant negative GCA effects for days to flowering. Mean values of parents for DDE ranged from $1086.31{ }^{\circ} \mathrm{C}$ to $1155.70{ }^{\circ} \mathrm{C}$ in RAS3/99 and PF7045/91, respectively. RAS3/99 and RGS003 with low mean values of DDE $\left(1086.25^{\circ} \mathrm{C}\right.$ and 1094.75 ${ }^{\circ} \mathrm{C}$, respectively) were preferred for improving this trait, both of these parents had significant negative GCA effects for DDE. DFP of parents was varied from $225.2^{\circ} \mathrm{C}$ to $298.03^{\circ} \mathrm{C}$ in RAS3/99 and RGS003, respectively. $19 \mathrm{H}$ and RGS003 with $271.75^{\circ} \mathrm{C}$ and $298.03^{\circ} \mathrm{C}$ of DFP were good parents for improving this trait. RGS003and PF7045/91 with significant positive GCA effects of DFP were good combiners for this trait (Table 4). Significant negative correlation between DDF and DFP, indicated that the genotypes with low mean values of DDF had high mean values of DFP (Table 3). DDM of parents ranged from $1484.55^{\circ} \mathrm{C}$ to $1641.30^{\circ} \mathrm{C}$ in RGS003 and PF7045/91, respectively. In north provinces of Iran, early maturity is desirable trait to have enough opportunity for second crops like rice and soybean, therefore the genotypes including RGS003 and Option500 with low mean values of this trait will be preferable. RGS003 with significant negative GCA effect of DDM was best combiner for improving this trait. Significant positive correlation between DDM and each of two traits including DDF and DDE, indicating these traits can be used as indirect selection criteria for improving DDM. SY was varied from $2218.58^{\circ} \mathrm{C}$ to $3131.92^{\circ} \mathrm{C} \mathrm{kg} \times \mathrm{ha}^{-1}$ in 
Option500 and PF7045/91, respectively. PF7045/91 with significant positive GCA effect of SY, was best combiner for improving SY. Rameeh (2010) and Amiri-Oghana et al.,( 2009) reported significant positive GCA effects of parents for grain yield in spring and winter rapeseed, respectively.

Table 3

Pearson correlation between the traits

\begin{tabular}{lccccc}
\hline \multicolumn{1}{c}{ Parents } & 1-DDF $\left({ }^{\circ} \mathrm{C}\right)$ & 2-DDE $\left({ }^{\circ} \mathrm{C}\right)$ & 3-DFP $\left({ }^{\circ} \mathrm{C}\right)$ & 4-DDM $\left({ }^{\circ} \mathrm{C}\right)$ & 5-SY $\left(\mathrm{kg} \times \mathrm{ha}^{-1}\right)$ \\
\hline 1- DDF $\left({ }^{\circ} \mathrm{C}\right)$ & 1 & & & & \\
2- DDE $\left({ }^{\circ} \mathrm{C}\right)$ & $0.73^{* *}$ & 1 & & & \\
3- DFP $\left({ }^{\circ} \mathrm{C}\right)$ & $-0.44^{* *}$ & 0.29 & 1 & & \\
4- DDM $\left({ }^{\circ} \mathrm{C}\right)$ & $0.71^{* *}$ & $0.73^{* *}$ & -0.03 & 1 & \\
5- $\mathrm{SY}\left(\mathrm{kg} \times \mathrm{ha} a^{-1}\right)$ & -0.11 & 0.06 & 0.24 & -0.07 & 1 \\
\hline
\end{tabular}

**: Significant at $\mathrm{p}=0.01$; DDF: growing degree days (GDDs) to the flowering; DDE: GDDs to end of flowering; DFP: GDDs for flowering period; DDM: GDDs to maturity; SY: Seed yield

Estimates of GCA effects for for growth degree day of phonological traits and seed yield in six parents of B. napus

\begin{tabular}{|c|c|c|c|c|c|}
\hline Parents & $\operatorname{DDF}\left({ }^{\circ} \mathrm{C}\right)$ & $\mathrm{DDE}\left({ }^{\circ} \mathrm{C}\right)$ & $\operatorname{DFP}\left({ }^{\circ} \mathrm{C}\right)$ & $\operatorname{DDM}\left({ }^{\circ} \mathrm{C}\right)$ & SY $\left(\mathrm{kg} \times \mathrm{ha}^{-1}\right)$ \\
\hline 1-RAS3/99 & 1.51 & $-9.61 * *$ & $-11.11 * *$ & -2.51 & 43.22 \\
\hline 2-RW008911 & $9.05 * *$ & 3.60 & -5.45 & -5.32 & -31.50 \\
\hline $3-19 \mathrm{H}$ & 4.56 & $4.93 *$ & 0.37 & 5.74 & -80.48 \\
\hline 4-RGS 003 & $-29.87 * *$ & $-18.49 * *$ & $11.38^{* *}$ & $-46.63 * *$ & 55.50 \\
\hline 5-Option 500 & -2.31 & -4.16 & -1.85 & -7.13 & $-173.01 * *$ \\
\hline 6-PF7045/91 & $17.07 * *$ & $23.73 * *$ & $6.66^{*}$ & $55.85 * *$ & $186.26^{* *}$ \\
\hline
\end{tabular}

*,** Significant at $\mathrm{p}<0.05$ and 0.01 , respectively; DDF: growing degree days (GDDs) to the flowering; DDE: GDDs to end of flowering; DFP: GDDs for flowering period; DDM: GDDs to maturity; SY: Seed yield

\section{Specific combining ability (SCA) and per se performance of crosses}

Mean values of DDF were varied from $809.48^{\circ} \mathrm{C}$ to $882.70^{\circ} \mathrm{C}$ in RGS003 $\times$ Option500 and RAS3/99 $\times$ PF7045/91, respectively (Table 5). The crosses including RGS003 $\times$ Option500, RAS3/99 $\times$ RGS003, $19 \mathrm{H} \times$ RGS003 and RW008911 × PF7045/91 with low mean values of DDF were considered as good cross combinations. Due to high narrow sense heritability estimates and prime importance of additive genetic effects for DDF, a few crosses had significant SCA effects for this trait. The crosses including RGS003 $\times$ Option500 and Option500 $\times$ PF7045/91 with significant 
negative SCA effects were good combinations for improving this trait (Table 6). This finding is in agreement to earlier studies on spring cultivars of oilseed rape have shown the important role of SCA effects for phenological traits (Nassimi, et al., 2006) and also winter cultivars of this species (Sabaghnia, et al., 2010). The crosses including $19 \mathrm{H} \times \mathrm{RGS003}$ and RW008911 $\times$ PF7045/91 with $1080.43^{\circ} \mathrm{C}$ and $1162.63^{\circ} \mathrm{C}$ mean values of DDE had highest and lowest mean amounts of this trait. The crosses including RW008911 $\times$ PF7045/91, 19H $\times$ PF7045/91 and RAS3/99 $\times$ PF7045/91 with high mean values of DDE were favorable combinations for improving this trait. RAS3/99 $\times$ Option500 and RW008911 $\times$ PF7045/91 with significant positive SCA effects for DDE were good combinations for increasing this trait. DFP ranged from $237.10^{\circ} \mathrm{C}$ to $283.25^{\circ} \mathrm{C}$ in $19 \mathrm{H} \times \mathrm{RGS003}$ and RW008911 $\times$ PF7045/91, respectively. The crosses including RW008911 × PF7045/91, RGS003 $\times$ Option500 and Option500 $\times$ PF7045/91 with high mean value of DFP were good combinations. Among the crosses only RW008911 × PF7045/91 had significant positive SCA effects for DFP and one of the parents of this combination had also significant positive GCA effect for this trait.DDM ranged from 1430.75 to 1594.35 in $19 \mathrm{H} \times \mathrm{RGS003}$ and RAS3/99 $\times \mathrm{PF} 7045 / 9$,respectively. The crosses including $19 \mathrm{H} \times \mathrm{RGS003}$, RAS3/99 $\times$ RGS003 and RGS003 $\times$ Option500 with $1430.75^{\circ} \mathrm{C}, 1440.23^{\circ} \mathrm{C}$ and $1447.53^{\circ} \mathrm{C}$ of DDM, respectively had low mean values of this trait and were desirable combinations. Most of crosses with low mean values of DDM had at least one parent with low mean value of this trait. The combinations including RAS3/99 x19H, RAS3/99 $\times$ RGS003, RW008911 $\times$ PF7045/91, 19H $\times$ RGS003 and RGS003 $\times$ PF7045/91 with significant negative SCA effects for DDM were good cross combinations. All of the combinations with significant negative SCA effects for DDM had at least one parent with significant negative GCA effect for this trait. The crosses including RAS3/99 $\times$ RW008911, RAS3/99 $\times$ RGS003, 19H $\times$ PF7045/9 and Option500 $\times$ PF7045/91 with $3347.50,3375,3320.83$ and $3431.17 \mathrm{~kg} \mathrm{ha}^{-1}$ of SY, respectively had high mean values of this trait. RAS3/99 $\times$ RW008911 and Option500 $\times$ PF7045/91 with significant positive SCA effects for SY were good combinations. Similarly, in earlier studies were reported significant SCA effect of crosses for grain yield in on various studies on spring (Hung, et al., 2010, Rameeh 2011) and winter (Amiri-Oghana and et al., 2009; Sabaghnia, et al., 2010) cultivars of oilseed rape. 
The means of growth degree day (GDD) of phonological traits and seed yield in diallel crosses of six parents of B.napus.

\begin{tabular}{|c|c|c|c|c|c|}
\hline Crosses & $\operatorname{DDF}\left({ }^{\circ} \mathrm{C}\right)$ & $\operatorname{DDE}\left({ }^{\circ} \mathrm{C}\right)$ & $\operatorname{DFP}\left({ }^{\circ} \mathrm{C}\right)$ & $\operatorname{DDM}\left({ }^{\circ} \mathrm{C}\right)$ & SY $\left(\mathrm{kg} \times \mathrm{ha}^{-1}\right)$ \\
\hline 1- RAS3/99 × RW008911 & 862.88 & 1103.40 & 240.53 & 1526.71 & 3347.50 \\
\hline 2- RAS3/99 × 19H & 861.45 & 1122.73 & 261.28 & 1483.98 & 2982.50 \\
\hline 3- RAS3/99 × RGS 003 & 833.08 & 1087.50 & 254.43 & 1440.23 & 3375.00 \\
\hline 4- RAS3/99 × Option 500 & 867.58 & 1115.00 & 247.43 & 1504.88 & 2615.83 \\
\hline 5- RAS-3/99 × PF7045/91 & 882.70 & 1135.83 & 253.13 & 1594.35 & 3225.00 \\
\hline $6-\mathrm{RW} 008911 \times 19 \mathrm{H}$ & 870.30 & 1119.90 & 249.60 & 1514.48 & 2887.50 \\
\hline 7-RW008911 × RGS 003 & 846.13 & 1095.23 & 249.10 & 1461.65 & 3197.92 \\
\hline 8- RW008911 × Option 500 & 853.63 & 1102.80 & 249.18 & 1496.20 & 2675.00 \\
\hline 9- RW008911 × PF7045/91 & 879.38 & 1162.63 & 283.25 & 1540.51 & 3099.50 \\
\hline $10-19 \mathrm{H} \times \mathrm{RGS} 003$ & 843.33 & 1080.43 & 237.10 & 1430.75 & 2784.17 \\
\hline $11-19 \mathrm{H} \times$ Option 500 & 865.58 & 1109.05 & 243.48 & 1557.86 & 2956.67 \\
\hline $12-19 \mathrm{H} \times \mathrm{PF} 7045 / 91$ & 876.30 & 1140.38 & 264.08 & 1579.99 & 3320.83 \\
\hline 13- RGS $003 \times$ Option 500 & 809.48 & 1089.78 & 280.30 & 1447.53 & 2971.25 \\
\hline 14- RGS $003 \times$ PF7045/91 & 853.30 & 1123.45 & 270.15 & 1587.43 & 2643.34 \\
\hline 15- Option $500 \times$ PF7045/91 & 856.73 & 1130.00 & 273.28 & 1571.66 & 3431.17 \\
\hline $\operatorname{LSD}(\alpha=0.01)$ & 28.20 & 26.41 & 36.20 & 50.92 & 719.2 \\
\hline
\end{tabular}

DDF: growing degree days (GDDs) to the flowering; DDE: GDDs to end of flowering; DFP: GDDs for flowering period; DDM: GDDs to maturity; SY: Seed yield 
Estimates of SCA effects for for growth degree day of phonological traits and seed yield in the half diallel crosses of six parents of B. napus $L$.

\begin{tabular}{|c|c|c|c|c|c|}
\hline Crosses & $\mathrm{DDF}\left({ }^{0 \mathrm{C}}\right)$ & $\operatorname{DDE}\left({ }^{0 \mathrm{C}}\right)$ & $\operatorname{DFP}\left({ }^{0 \mathrm{C}}\right)$ & $\operatorname{DDM}\left({ }^{0 \mathrm{C}}\right)$ & $\mathrm{SY}\left(\mathrm{kg} \mathrm{ha}^{-1}\right)$ \\
\hline 1- RAS3/99 × RW008911 & -7.35 & -6.85 & 0.50 & 4.58 & $411.34 *$ \\
\hline 2- RAS3/99 × 19H & -4.30 & 11.14 & 15.44 & $-49.22 * *$ & 95.33 \\
\hline 3- RAS3/99 × RGS 003 & 1.77 & -0.66 & -2.43 & $-40.59 * *$ & 351.84 \\
\hline 4- RAS3/99 × Option 500 & 8.71 & $12.51^{*}$ & 3.80 & -15.45 & -178.90 \\
\hline 5- RAS-3/99 × PF7045/91 & 4.45 & 5.44 & 0.99 & 11.05 & 71.08 \\
\hline $6-\mathrm{RW} 008911 \times 19 \mathrm{H}$ & -2.99 & -4.89 & -1.90 & -15.91 & 75.04 \\
\hline 7-RW008911 × RGS 003 & 7.28 & -6.14 & -13.42 & -16.36 & 249.47 \\
\hline 8- RW008911 × Option 500 & -12.78 & $-12.90 *$ & -0.11 & -21.32 & -44.93 \\
\hline 9- RW008911 × PF7045/91 & -6.42 & $19.04 * *$ & $25.45 * *$ & $-39.98 * *$ & 20.30 \\
\hline $10-19 \mathrm{H} \times \mathrm{RGS} 003$ & 8.96 & $-22.27 * *$ & $-31.23 * *$ & $-58.32 * *$ & -115.55 \\
\hline $11-19 \mathrm{H} \times$ Option 500 & 3.65 & -7.98 & -11.63 & $29.28 * *$ & 285.71 \\
\hline $12-19 \mathrm{H} \times \mathrm{PF} 7045 / 91$ & -5.01 & -4.55 & 0.46 & -11.57 & 290.61 \\
\hline 13-RGS $003 \times$ Option 500 & $-18.01 * *$ & -3.83 & 14.18 & $-28.68^{*}$ & 164.32 \\
\hline 14- RGS $003 \times$ PF7045/91 & 6.43 & 1.95 & -4.48 & $48.25 * *$ & $-522.87 * *$ \\
\hline 15- Option $500 \times$ PF7045/91 & $-17.71 * *$ & -5.83 & 11.88 & -7.02 & $493.47 * *$ \\
\hline
\end{tabular}

*, ** Significant at $\mathrm{p}<0.05$ and 0.01 , respectively; DDF: growing degree days (GDDs) to the flowering; DDE: GDDs to end of flowering; DFP: GDDs for flowering period; DDM: GDDs to maturity; SY: Seed yield

\section{CONCLUSION}

In general due to significant positive correlation between DDM and each of two traits including DDF and DDE, indicating these traits can be used as indirect selection criteria for improving DDM. DFP was also less heritable than the other phonological traits, so the efficiency of selection for this trait will be low. All of the combinations with significant negative SCA effects for DDM had at least one parent with significant negative GCA effect for this trait. PF7045/91 with significant positive GCA effect of SY, was best combiner for improving SY. RAS3/99 $\times$ RW008911 and Option500 $\times$ PF7045/91 with significant positive SCA effects for SY were good combinations for improving this trait. 


\section{ACKNOWLEDGEMENTS}

The author wishes to thank Agricultural and Natural Resources Research Center of Mazandaran and Seed and Plant Improvement Institute (SPII) for providing genetic materials and facility for conducting this experiment.

\section{REFERENCES}

Ali, M., L.O. Copeland, S.G. Elias, and J.D. Kelly. 1995. Relationship between genetic distance and heterosis for yield and morphological traits in winter canola (Brassica napus L.). Theor. Appl. Genet. 91:118-121. Amiri-Oghana, H, M.H Fotokianb, F. Javidfar and B. Alizadeh, 2009. Genetic analysis of grain yield, days to flowering and maturity in oilseed rape (Brassica napus L.) using diallel crosses. Inter. J. of Plant Production 2:19-26.

Azizinia, S. 2012. Combining Ability Analysis of Yield Component Parameters in Winter Rapeseed Genotypes (Brassica napus L.). J. of Agric. Sci. 4(4):87-94.

Cheema, K.L. and H.A. Sadaqat, 2004. Potential and genetic basis of drought tolerance in canola (Brassica napus): i. Generation mean analysis for some phenological and yield components. Int. J. Agric. Biol., 6: 74-81.

Diepenbrock, W., 2000. Yield analysis of winter oilseed rape (Brassica napus L.): A review. Filed Crop Res. $67,35-49$.

Downey, R.K. and S.R. Rimer. 1993. Agronomic improvement in oilseed brassicas. Adv. Agron. 50: 1-150.

Faraj, A., N. Latifi, A. Soltani and A.H. Shirani Rad. 2008. Effect of high temperature and supplemental irrigation in flower and pod formation in two canola (Brassica napus L.) cultivars at Mediterranean climate. Asian J. of Plant Sci. 7(4):343-351.

Gardner, C. O., and S.A. Eberhart. 1966. Analysis and interpretation of the variety cross diallel and related populations. Biometrics 22: 439-452.

Griffing, B., 1956. Concept of general combining ability in relation to diallel crossing system. Australian J. Biol. Sci., 9: 463-493.

Habekotte, B. 1997. Evaluation of seed yield determining factors of winter oilseed rape (Brassica napus L.) by means of crop growth modeling. Field Crops Res. 54, 137-151.

Huang. Z., P. Laosuwan, T. Machikowa and Z. Chen, 2010. Combining ability for seed yield and other characters in rapeseed. Suranaree J. Sci. Technol. 17(1):39-47.

Kearsey, M.J., and H.S. Pooni, 1996. The Genetical Analysis of Quantitative Traits. Chapman and Hall, London.

Kumar, A., V.K. Mishra, R.P. Vyas, and V. Singh. 2011. Heterosis and combining ability analysis in bread wheat (Triticum aestivum L.). J. of Plant Breed. and Crop Sci. 3(10): 209-217.

Malik, S.I., H.N. Malik, N.M. Minhas and M. Munir. 2004. General and specific combining ability studies in maize. Int. J. Agric. Biol., 6: 856-859.

Nassimi, A.W., A. Raziuddin Sardar and A. Naushad, 2006. Study on heterosis in agronomic characters of rapeseed (Brassica napus L.) using diallel. J. of Agron., 5: 505-508.

Sabaghnia, N., H. Dehghani, B. Alizadeh and M. Mohghaddam, 2010. Diallel analysis of oil content and some agronomic traits in rapeseed (Brassica napus L.) based on the additive-dominance genetic model. Australian J. of Crop Sci. 4(8):609-616

Singh, M., L. Singh and S.B.L. Srivastava. 2010. Combining ability analysis in Indian mustard (Brassica juncea). J. of Oilseed Brassica, 1(1): 23-27.

Teklwold, A.and H.C. Becker, 2005. Heterosis and combining ability in a diallel cross of Ethiopian mustard inbred lines. Crop Sci., 45(6): 2629-2635.

Thomas. P. 2003. Canola Grower's Manual. Canola Council of Canada. Winnipeg, Manitoba, pp. 307 and $1017 \mathrm{a}$.

Xiang, B., \& Li, B. (2001). A new mixed analytical method for genetic analysis of diallel data. Canadian J. for Res. 31: 2252-2259.

Zhang, G., W. Zhu , 2006. Genetic analyses of agronomic and seed quality traits of synthetic oilseed Brassica napus produced from interspecific hybridization of B. campetris and B. oleracesea. J Genet. 85: 45-51.

Zhang, Z. and S.K. Kang, 1997. A SAS Program for Griffing's Diallel Analyses. Agron. J. 89:176-182. 